\title{
Effect of different ratios of ginger solution concentrations on the quality of millet-based Kunun- Zaki
}

\begin{abstract}
This study evaluates the effect of Ginger solution concentrations (GSCs) on the quality of Millet-based Kunun-Zaki (MKZ). Six (6) samples of MKZ were prepared using millet, Ginger solution concentrate and sugar syrup and they were coded, 200 (KZ preserved with $0 \%$ GSC), 201 (KZ preserved with 5\% GSC), 202 (KZ preserved with $10 \%$ GSC), 222 (KZ preserved with 15\% GSC), 232 (KZ preserved with $20 \%$ GSC) and 242 (KZ preserved with $25 \%$ GSC). The findings of this study suggested that the $\mathrm{pH}$ values observed and recorded from the day 3 indicated that the samples 200, 201 and 202 were slightly acidic ranging from 3.13 to 3.40 , and the level of acidity of 3.32 increased more in sample of KZ coded 200 (the control sample); while on the day 1 and day 2 stable $\mathrm{pH}$ values of about 4.9 to 5.0 were recorded from samples 222, 232 and 242 , respectively. This study suggest that the GSC ratio of $15 \%, 20 \%$ and $25 \%$ controlled the $\mathrm{pH}$ of the MKZ effectively for about $72 \mathrm{hrs}$, while ratio of $5 \%$ and $10 \%$ showed a drop in $\mathrm{pH}$ within the $48 \mathrm{hrs}$ of production of $\mathrm{MKZ}$, while the control $(0 \%$ GSC) showed a drop in $\mathrm{pH}$ within $24 \mathrm{hrs}$ of the production of MKZ. Also, the results of the sensory analysis conducted on the samples of $\mathrm{MKZ}$ indicate that the sensory properties of MKZ were stable for 48-72 hrs without any adverse change. This study concludes that this standard operating procedure (SOP) established from this study can be adopted for the commercial production of MKZ.
\end{abstract}

Keywords: millet-based Kunun-Zaki, ginger solution concentrations, ph value, sensory quality

\section{Introduction}

The consumption of 'Kunun-zaki' (KZ) originated from the Northern Nigeria, but it is becoming popular among Nigerians in respective of class, age and geographical location. ${ }^{1-4} \mathrm{KZ}$ is a cerealbased beverage which is prepared either from the slurry of Millet, Sorghum, Rice, and Maize. ${ }^{5} \mathrm{KZ}$ is rich in carbohydrates, vitamins, and minerals but low in protein. ${ }^{2,6} \mathrm{KZ}$ is locally made by milling grains steeped over-night with spices, such as black pepper, clove, and ginger and sweet potatoes. ${ }^{2,7}$ For the purpose of this study Milletbased Kunun-Zaki (MKZ) was prepared. The need to produce sensory stable and commercially viable $\mathrm{KZ}$ by adding a suitable ratio of Ginger solution concentration prompted this study. This is because the sensory attributes of Kunu zaki last for 12-24 hrs only making it highly perishable beverage drink..$^{1,3,4}$

This research is aimed at evaluating the significance of spicing MKZ using a suitable ratio of Ginger concentrations solution for the purpose of monitoring its sensory attributes, $\mathrm{pH}$ value and the establishment of standard operating procedure (SOP) for commercial $\mathrm{KZ}$ production. Hence the need for the utilization of local raw materials, such as the Millet (i.e. Pennisetum typhoides) and Ginger (Zingiber Officinate), and the requirement for the adoption of a suitable ratio of Ginger solution concentration for the production of quality and safe traditional beverage known as Kunun-zaki (KZ) in Nigeria prompted this research.

\section{Introduction to Kunu-Zaki (KZ)}

Several studies have established and reported that $\mathrm{KZ}$ is a product of lactic acid fermentation. ${ }^{4,8} \mathrm{KZ}$ is a product of cereals and spices,
Volume 6 Issue 6 - 2018

\author{
Mohammed SF \\ Department of Food Science and Technology, School of Science \\ and Technology, Nigeria
}

\begin{abstract}
Correspondence: Mohammed SF, Department of Food Science and Technology, School of Science and Technology, The Federal Polytechnic, PMB I0 12, Kaura-Namoda, Zamfara state, Nigeria,Emailsmfumtua@gmail.com, sirajfumtua.fst@fedponam.edu.ng
\end{abstract}

Received: November 12, 2018 | Published: December II, 2018 such as the ginger and black pepper, and sugar; some home producers add sweet potatoes in the production of KZ to improve its taste and sweetness. ${ }^{4}$ And it is produced at cottage level by most house wives to support the income of the family, and it is commonly consumed among the people domiciling in the northern parts of Nigeria. $\mathrm{KZ}$ is usually sold at schools and markets. ${ }^{4}$ Also, an attempt to package and commercialize $\mathrm{KZ}$ has been in progress, ${ }^{25}$ and packaging of $\mathrm{KZ}$ can be successfully accomplished if it is properly prepared. The objective of this study is to produce safe and quality $\mathrm{KZ}$ prepared from the slurry of Millet, sweetened with inverted sugar syrup and spiced with suitable ratio of Ginger solution concentration.

\section{Methods Used for $\mathrm{KZ}$ production}

$\mathrm{KZ}$ is produced by different methods as reported by various studies. ${ }^{1,2,4,7-11}$

\section{Production of KZ by pre-fermentation}

Millet are sorted, washed and steeped in water together with spices (ginger, dried potatoes, black pepper) for about 5 hours in-order to aid fermentation, it was later wet-milled and the paste was divided into two equal portions in which hot water was poured on one portion and allowed to cool before mixing it together with the other remaining portion, it was sieved and Sugar was added to a desire taste. ${ }^{7}$ Another method for the production of $\mathrm{KZ}$ is the post-fermentation process as described by a study of Efiuvwevwere \& Akoma. ${ }^{7}$

\section{Production of $K Z$ by post-fermentation}

Millet is steeped in water for 24 hours, wet millet and sieved. The sediment obtained is divided into two unequal portions; one portion 
is cooked and then mixed with uncooked portion (being the source of inoculum) and allowed to ferment for 8-10 hours. ${ }^{7}$ Another method for the production of $\mathrm{KZ}$ is the malting process as described by a study of Awogbenga \& Ahmadu. ${ }^{9}$

\section{Production of KZ by malting}

Malting process is achieved by weighing $150 \mathrm{~g}$ of sorghum which will be washed with tap water and steeped in $250 \mathrm{ml}$ of tap water for 12 hours and then drained. The drained grain was couched by covering them with moist cloth for 3-4 days at ambient temperature $\left(25-30^{\circ} \mathrm{C}\right)$ to germinate. This dried malted sorghum was ground and packed in cellophane bags. The malted Sorghum is then dried, grind and mixed with the uncooked portion. The mixture is then added to the cooked portion and stirred vigorously and allowed to ferment. ${ }^{9} \mathrm{KZ}$ can be produced by the use multiple cereals including millet, maize and sorghum by a study published by Steinkraus. ${ }^{12}$

\section{Production of KZ from millet, maize and sorghum}

Millet, maize and sorghum were cleaned and steeped in a tap water for 24 hours, mixed spices (ginger, black pepper and clove) and washed in fresh tap water before wet milling. The resulting slurry was sieved in excess tap water. Following sedimentation, both the cooked and uncooked paste $\left(\right.$ at $45^{\circ} \mathrm{C}$ ) were mixed in an unequal ratio of $(1: 3)$, following dilution with 3 volume water. The mixture was allowed to ferment for $8-10 \mathrm{hrs}$ at a temperature of $37^{\circ} \mathrm{C}$ to $40^{\circ} \mathrm{C}$, and then sweetened with sugar to taste., ${ }^{2,12}$

\section{Nutritional quality and probiotic properties of $\mathbf{K Z}$ produced by several methods}

KZ produced from various cereals and by different methods has been reported by several studies to have excellent nutrients and lower glycemic effect., ${ }^{9,11,13}$ Several studies have shown that hydrolytic enzyme (amylase) in the malted grain aids in digesting the thick slurry thereby converting the complex carbohydrate to simple sugars. The final product is usually taste sweet without the addition of any sweetening agent. ${ }^{13}$ Also another study on glycemic effect of $\mathrm{KZ}$ on the blood glucose in non-diabetic person shows that KZ has similar response but lower glycemic index as compared with those of high energy drinks (glucose) suggesting that KZ would be beneficial to diabetic patient. ${ }^{9}$ This could be attributed to the availability of simple sugars such as the Fructose in the KZ which has the ability to lower the blood Glucose in the body. ${ }^{14}$ In addition, $\mathrm{KZ}$ is an excellent source of micronutrients and macronutrients including sugars (sucrose), calcium, phosphorus, protein and iron. ${ }^{1,2,4}$ On the average, $\mathrm{KZ}$ contains $86.3 \%$ moisture, $3.83 \%$ protein, $0.16 \%$ ash, and $15 \mathrm{mg} / 100 \mathrm{ml}$ vitamin C. ${ }^{11}$

But with the already established nutritional known quality of $\mathrm{KZ}$ highlighted above, several studies have reported the probiotic properties of $\mathrm{KZ}$ due to presence of lactic acid bacteria such as Lactobacillus brevis, Streptococcus lutetensis, Weissella confusa, Streptococcus gallolyticus and Bifidobacterium species. ${ }^{15}$ Probiotic bacteria ease digestive distress, lower cholesterol level, slow down ageing process, boost energy and improve immunity. ${ }^{11,15,16}$ In addition, lactic acid bacteria activate the synthesis and assimilation of vitamin $\mathrm{C}$ and minerals in the body. ${ }^{11,16}$

Spices such as the ginger, clove and black pepper are used in the production of $\mathrm{KZ}$ in order to improve its taste, and ginger is widely used for culinary purposes in baked products. ${ }^{4}$

\section{Botanical characteristic of ginger plant}

Ginger (Zingiber Officinate Roscoe) is a monocotyledon belonging to the family of zingiberaceae which are aromatic, and some of the species of the Ginger are non-aromatic. ${ }^{4}$ Ginger is obtained from the perennial plant Zingiber officinate which grows up to $2 \mathrm{ft}$ in height. The edible stem, used in sweet manufacturing is an underground root like scaly leaves and buds. Successful cultivation of Ginger requires frequent application of manure, a sufficiently, high rainfall and a high air temperature.

\section{Safety and quality issues associated with $\mathbf{K Z}$}

One of the major quality problems associated with $\mathrm{KZ}$ is that it is produced under poor sanitary conditions; poor handling of raw materials and ingredients resulting in short shelf life. ${ }^{17}$ This could be attributed to poor Good Manufacturing Practice (GMP) and poor Good Hygiene Practice (GHP) during processing of traditional beverages, such as KZ. ${ }^{18}$ One of the safety issues that require attention and addressing is the use of already used polyethylene terephthalate (PET) packages in packaging sweet beverages in Nigeria. Home-based producers of TBs including KZ use old PET bottles to package. Sometimes plastic bottles and/or Polyethylene-based packages are used for packaging and presenting KZ to consumers. Research work has shown the risks associated with plastic polymers produced from synthetic materials. ${ }^{19}$ These plastics are used repeatedly by home producers of KZ to sell their products without knowing the implications of their action. The consumers continue to buy and consume KZ packaged in old PET containers due to illiteracy coupled with poverty. ${ }^{4}$

Traditional beverage including $\mathrm{KZ}$ has poor keeping quality due to unguided processing methods and poor storage. ${ }^{20}$ It is also known to be prone to microbial contamination. ${ }^{17}$ There are several microbial contaminants associated with $\mathrm{KZ}$ including Aspergillus and Penicillium species. ${ }^{20}$ They are both toxigenic fungi including the Fusarium specie. ${ }^{21}$ Fusarium is commonly isolated from cereals, and it is the most prevalent toxin-producing fungi. ${ }^{22}$ In developing nations such as Nigeria, it has been noted that Fuminosins and Aflotoxins are likely to be of significance, and they are produced by three species of Aspergillus namely A. flavus, A. parasiticus and A. nomius ${ }^{21-23}$ Aflotoxins are group of mycotoxins of most concern because they are having both hepatotoxins and carcinogens. ${ }^{22}$

Also, Ochratoxin A (OTA) has been reported in foodstuffs especially the cereals and their products, for example OTA $(50 \mathrm{mg} / \mathrm{kg})$ has been identified in the cereal (millet) used for the production of KZ. ${ }^{17}$ Therefore, the important foodborne mycotoxins (FMT) formation due to Aspergillus niger contamination include Aflotoxins, Ochratoxins, Fuminosins and Malformins., ${ }^{4,22,23}$ The sensory and keeping quality of $\mathrm{KZ}$ might improve by the addition of ginger solution concentrates in a certain proportion so that shelf life and storage optimization can be improved. ${ }^{16}$

\section{Materials and methods}

Materials required for the production of Millet-based Kunun-zaki (MKZ) and Ginger concentration solution (GCS) include, Millet, Ginger (fresh), granulated sugar and potable water.

\section{Sources of materials}

The millet, ginger (fresh) and granulated sugar were purchased in Kaura-Namoda Central market, Kaura-Namoda. Other materials 
used were sourced from the Federal Polytechnic, Kaura-Namoda, department of Food Technology, Food Processing workshop, for the production of MKZ and GCS are weighing balance, potable water, pressure cooker, stove, muslin cloth $(0.0025 \mathrm{~mm})$, stainless pot, bowl (plastic), stirrer and thermometer.

\section{Methodology for production of GCS}

One method was adopted in the extraction of Ginger solution concentrates was a boiling method..$^{24,25}$

\section{Boiling method for the production of Ginger solution concentrates}

$5 \mathrm{~g}$ of weighed ginger was peeled and sliced into small pieces, it was then ground with pestle and mortar in order to lose the tissues for easy penetration of water, then $95 \mathrm{ml}$ of potable water was added and it was brought to boil at $100^{\circ} \mathrm{C}$ for 5 minutes and allowed to cool to about $40^{\circ} \mathrm{C}$ and filtered with the clean muslin cloth of sieve size $0.0025 \mathrm{~mm}$. Other concentrations solutions of Ginger were prepared in the same manner as demonstrated in Table 1 and Figure 1.24,26,27

\section{Methods for production of Millet-based Kunun-zaki}

There are several methods employed in the production of MKZ. Methods such as the pre-fermentation, post-fermentation, and malting are always used in the preparation of MKZ. ${ }^{7,9}$ For the purpose of this study the post-fermentation method was adopted and used for this study.

\section{Production of millet-based Kunun-zaki by post fermentation process}

$250 \mathrm{~g}$ of millet was sorted, cleaned and steeped in a potable water before it was wet-milled, the resulting slurry was divided into two portions (i.e. $250 \mathrm{~g}$ and $50 \mathrm{~g}$ ), boiled water was poured on one slurry $(250 \mathrm{~g})$ and allowed to cool before it was mixed vigorously with
Table I Preparation of Ginger solutions of various concentrations by boiling metho

\begin{tabular}{llllll}
\hline Sample & Weight of ginger $(\mathbf{g})$ & Time $(\mathbf{m i n})$ & Temperature $\left({ }^{\circ} \mathbf{C}\right)$ & GCS $(\%)$ & Water $(\mathbf{m l})$ \\
\hline 201 & 5 & 5 & 100 & 5 & 95 \\
212 & 10 & 10 & 100 & 10 & 90 \\
222 & 15 & 15 & 100 & 15 & 85 \\
232 & 20 & 20 & 100 & 20 & 80 \\
242 & 25 & 25 & 100 & 25 & 75 \\
\hline
\end{tabular}

\section{Procedure for the production of inverted sugar syrup}

$150 \mathrm{~g}$ granulated sugar was weighed into a plastic bowl, mixed with $200 \mathrm{ml}$ of potable water and then heated for 25 minutes at $100^{\circ} \mathrm{C}$, a drop of concentrated Sulphuric acid $\left(\mathrm{H}_{2} \mathrm{SO}_{4}\right)$ was added and reheated for $10-15$ minutes at $100^{\circ} \mathrm{C}$, it was allowed to cool to form sugar syrup (Figure 1). The inversion of sucrose is the hydrolysis (i.e. breakdown) of Sucrose into monosaccharide Glucose and Fructose. Hydrolysis reactions are promoted by the presence of acid, enzyme or high temperature if this occurs in a beverage during storage, sweetness increases because Fructose is generated by the reaction. In addition, some of the factors that promote sucrose inversion are low storage, $\mathrm{pH}$ which means high acidity and high storage temperature. In some products, inversion is desirable and is created by the action of enzyme, inverters or by action of an acidulant. ${ }^{28}$ below. concentrates were added into Millet Kunun-zaki (MKZ) at different ratios and was subjected to $\mathrm{pH}$ determination for three days.

\section{Procedure for $\mathrm{pH}$ determination} was determined using reference $\mathrm{pH}$ Meter (Model 291 MK2PYE uncooked slurry $(50 \mathrm{~g})$, the mixture was allowed to ferment for 14 hours at $40^{\circ} \mathrm{C}$,then sieved with clean muslin- cloth $(0.0025 \mathrm{~mm})$ and was sweetened with sugar syrup (Figure 1). ${ }^{7}$

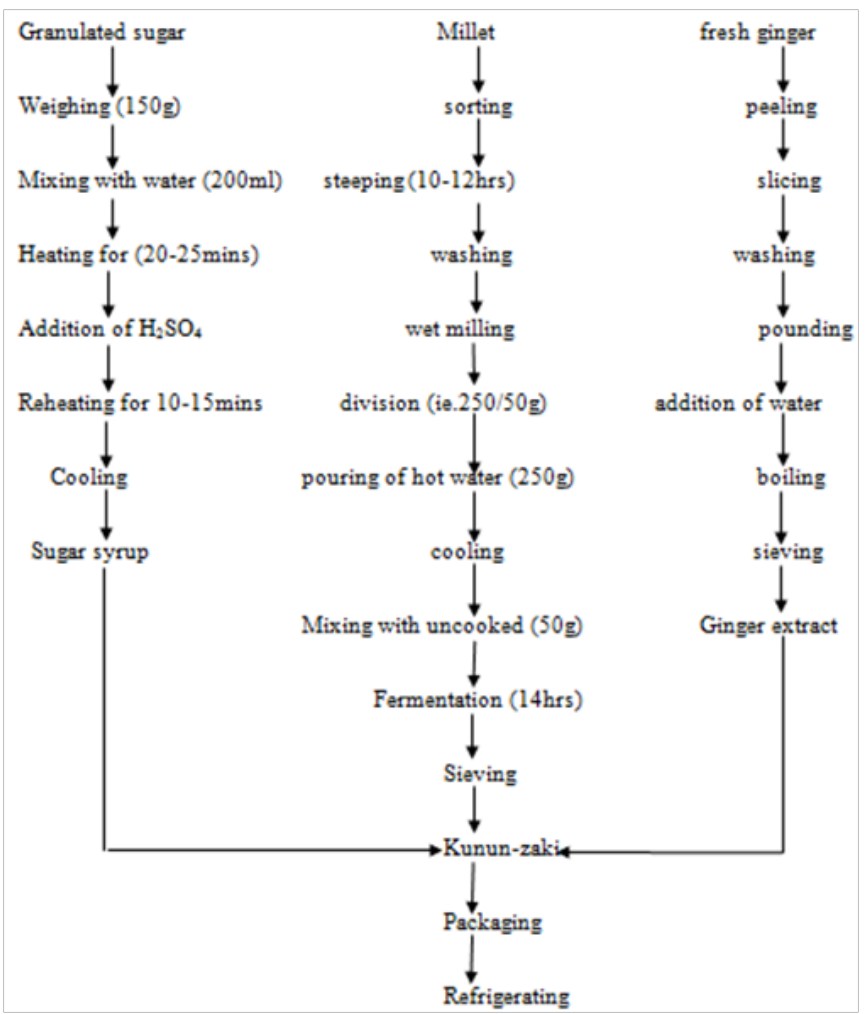

Figure I Process flow diagram for the production of $\mathrm{KZ}$ using ginger extract and sugar syrup.

Sources: ${ }^{7,28}$

\section{Addition of ginger Solution concentrations at different ratios in $M K Z$}

Ginger concentration solutions (GCS) was added into the different samples of Millet-based Kunun-zaki (MKZ) as itemized in Table 2

The Table 3 above is an illustration of how Ginger solution

The determination of $\mathrm{pH}$ was carried out in triplicates. The $\mathrm{pH}$ UNICAM, England). The electrode was fixed on a $\mathrm{pH}$ meter and was 
calibrated using screw and potable water at 7.2 , then $10 \mathrm{ml}$ of $\mathrm{MKZ}$ was taken from each sample into six cleaned beakers, the $\mathrm{pH}$ metre was dipped into each sample for three times and the reading were all recorded. This was done for 72 hours (i.e. 3 consecutive days). ${ }^{13}$

Table 2 A summary of ratios of GCS added into $M K Z$

\begin{tabular}{llll}
\hline Sample & MKZ $(\mathrm{ml})$ & GCS $(\%)$ & GCS $(\mathrm{ml})$ ratio \\
\hline 200 & 100 & 0 & 0 \\
201 & 95 & 5 & 5 \\
212 & 90 & 10 & 10 \\
222 & 85 & 15 & 15 \\
232 & 80 & 20 & 20 \\
242 & 75 & 25 & 25
\end{tabular}

Table 3 Results of $\mathrm{pH}$ values of MKZ Samples for 24 hrs (day I)

\begin{tabular}{lll}
\hline Serial no. & Sample code & $\mathbf{p H}$ \\
\hline 1 & 200 & $5.2 \pm 0.20^{\mathrm{b}}$ \\
2 & 201 & $5.0 \pm 0.26^{\mathrm{b}}$ \\
3 & 212 & $5.1 \pm 0.10^{\mathrm{a}}$ \\
4 & 222 & $5.0 \pm 0.10^{\mathrm{a}}$ \\
5 & 232 & $4.9 \pm 0.16^{\mathrm{c}}$ \\
6 & 242 & $4.9 \pm 0.15^{\mathrm{c}}$ \\
\hline
\end{tabular}

'Each value is the mean standard error $( \pm)$ of triplicate determinations. ${ }^{2}$ Different letters within the same column with each test are significantly different $(p<0.05)$.

\section{Sensory evaluation}

The sensory attribute (taste) of processed kunu-zaki was evaluated for three days consecutively by the same 10 panelists comprising of students of various departments from Federal Polytechnic KauraNamoda. The method used for this sensory analysis is ranking method. ${ }^{29,30}$

\section{Ranking method}

Six samples that were coded 200 (KZ preserved with $0 \%$ GEC), 201 (KZ preserved with 5\% GEC), 202 (KZ having 10\% GEC), 222 (KZ having 15\% GEC), 232 (KZ preserved with 20\% GEC) and 242 (KZ preserved with $25 \%$ GEC) were presented along with score sheet (questionnaire) to 10 sensory panelists and they were asked to rank the samples based on mouth-feel only. ${ }^{29,30}$

During this ranking, the panelists are not allowed to have ties, thus the method will be forces choice. ${ }^{31,32}$ The sample were ranked from most liked to least liked using the following numbers 5-1, where $5=$ least liked and $1=$ most liked, the ranking was done for every $24 \mathrm{hrs}$ for three days to actually detect the effect of ginger extract concentration on the sensory quality of processed KZ.

\section{Results}

\section{Results of $\mathrm{pH}$ values of $\mathrm{KZ}$ samples}

This part of the study presents and discusses the results of the $\mathrm{pH}$ values conducted on the samples of Kunun-Zaki (KZ) stored and observed for 72 hrs (i.e. 3 days, consecutively). The $\mathrm{pH}$ value of a food is a direct function of the free hydrogen ions present which are released into the food, which give foods that acidity and their distinct sour flavour. ${ }^{33}$ This implies that if a food has a $\mathrm{pH}$ value of 3 , then the concentration of hydrogen ions present in that food is equal to $10^{-3}$ (0.001) Moles/litre. ${ }^{33}$

\section{Discussion}

The results from $\mathrm{pH}$ of the day 1 analysis (Table 4) shows that the MKZ is acidic as a result of fermentation that took place during the production of MKZ which resulted to breaking down of carbohydratelike substances by microorganisms, and the standard deviations indicated how closely the level of acidity in each sample is to each other $(\mathrm{p}<0.05) .{ }^{29}$ The results of day 1 are agreement with the results reported by Obulunde \& Ogunkoya; ${ }^{34}$ Agarry \& Nkama; ${ }^{35}$ Maji \& James $;{ }^{1}$ Edward \& Oheagbu. ${ }^{36}$

Table 4 Results of $\mathrm{pH}$ values of MKZ Samples for 48 hrs (day 2)

\begin{tabular}{lll}
\hline Serial no. & Sample code & pH \\
\hline 1 & 200 & $5.1 \pm 0.10^{\mathrm{a}}$ \\
2 & 201 & $5.2 \pm 0.10^{\mathrm{a}}$ \\
3 & 212 & $4.9 \pm 0.05^{\mathrm{b}}$ \\
4 & 222 & $5.0 \pm 0.05^{\mathrm{b}}$ \\
5 & 232 & $5.0 \pm 0.05^{\mathrm{b}}$ \\
6 & 242 & $4.9 \pm 0.02^{\mathrm{c}}$ \\
\hline
\end{tabular}

'Each value is the mean standard error $( \pm)$ of triplicate determinations. ${ }^{2}$ Different letters within the same column with each test are significantly different $(p<0.05)$.

Results of the $\mathrm{pH}$ values (Table 4) showed that there is no much difference in $\mathrm{pH}$ values of day 2 and that of day 1 probably because of the effect of GSC and cold storage condition $\left(4-5^{\circ} \mathrm{C}\right.$ for $24-48$ hrs) that the samples of MKZ were preserved with GSC of various concentrations and stored in the refrigerator during the 2 days of study which as a result of that likely inhibits further fermentation of the samples. Also, the results of day 2 are in agreement with the results of Obulunde \& Ogunkoya; ${ }^{34}$ Agarry \& Nkama; $;{ }^{35}$ Maji \& James; $;{ }^{1}$ Edward \& Oheagbu. ${ }^{36}$

Results of the $\mathrm{pH}$ values (Table 5) showed that the level of acidity has increased because of the $\mathrm{pH}$ values dropped from 5.1 to the ranges of 3.2 to 3.4 suggesting that there was further lactic fermentation during storage possibly due to the activities of lactic acid bacteria (LAB) as a result of the accelerated growth of the LAB making the samples of the MKZ more acidic. ${ }^{12,37,38}$

Table 5 Results of $\mathrm{pH}$ values of MKZ samples for $72 \mathrm{hrs}$ (day 3)

\begin{tabular}{lll}
\hline Serial no. & Sample code & $\mathbf{p H}$ \\
\hline 1 & 200 & $3.32 \pm 0.02^{\mathrm{c}}$ \\
2 & 201 & $3.16 \pm 0.15^{\mathrm{b}}$ \\
3 & 212 & $3.30 \pm 0.1^{\mathrm{a}}$ \\
4 & 222 & $3.13 \pm 0.15^{\mathrm{b}}$ \\
5 & 232 & $3.40 \pm 0.1^{\mathrm{a}}$ \\
6 & 242 & $3.40 \pm 0.1^{\mathrm{a}}$
\end{tabular}

'Each value is the mean standard error $( \pm)$ of triplicate determinations. ${ }^{2}$ Different letters within the same column with each test are significantly different $(p<0.05)$.

Also, the results of day 3 are in close agreement with the results of Obulunde \& Ogunkoya ${ }^{34}$ Agarry et al. $;^{35}$ and Edward \& Oheagbu. ${ }^{36}$ 
Also, the drop in $\mathrm{pH}$ may be as a result of greater microbial activities since this decrease was more observed in the control samples having $0 \%$ GSC. The high rate of change in $\mathrm{pH}$ with storage days could be due to the decomposition of fermentable substrates and sugars by microorganisms especially Lactobacillus species, a lactic acid bacteria, which could comfortably ferment carbohydrates to produce energy and lactic acid. ${ }^{12,36}$

\section{Results of Sensory analysis of samples of $\mathbf{K Z}$ stored and observed for 3 days}

This part of the study presents and discusses the results of the sensory evaluation conducted on the samples of $\mathrm{ZD}$ stored and observed for 3 days (Table 6-10).

Table 6 Results of sensory evaluation (ANOVA) conducted for dayl 6

\begin{tabular}{llllll}
\hline Sources of variation & Df & Ss & Ms & F. cal & F. tab \\
\hline Samples & 5 & 6.020 & 1.20 & 4.4 & 4.03 \\
Judges & 9 & 2.43 & 0.27 & & \\
Error & 45 & 34.18 & 0.76 & & \\
Total & 59 & & & & \\
\hline
\end{tabular}

Table 7 Summary of ranked results of sensory evaluation conducted for day

\begin{tabular}{llll}
\hline Samples & T. cal & T. tab & Remark \\
\hline $200-212$ & -0.57 & 1.18 & SD \\
$200-201$ & 0.32 & 1.18 & SD \\
$201-222$ & 0.65 & 1.18 & SD \\
$201-232$ & 0.40 & 1.18 & SD \\
$212-242$ & -0.07 & 1.18 & SD \\
$242-200$ & 0.26 & 1.18 & SD
\end{tabular}

Table 8 Results of sensory evaluation (ANOVA) conducted for day 2

\begin{tabular}{llllll}
\hline Sources of variation & Df & Ss & Ms & F. cal & F. tab \\
\hline Samples & 5 & 26.42 & 5.28 & 18.21 & 4.03 \\
Judges & 9 & 2.59 & 0.29 & & \\
Error & 45 & 13.52 & 0.30 & & \\
Total & 59 & & & & \\
\hline
\end{tabular}

Table 9 Summary of ranked results of sensory evaluation conducted for day 2

\begin{tabular}{llll}
\hline Samples & F. cal & F. tab & Remark \\
\hline $232-242$ & 0.92 & 0.72 & NSD \\
$222-242$ & 0.92 & 0.72 & NSD \\
$200-212$ & -0.55 & 0.72 & SD \\
$200-232$ & -0.01 & 0.72 & SD \\
$242-212$ & 0.38 & 0.72 & SD \\
$242-232$ & 0.92 & 0.72 & NSD \\
\hline
\end{tabular}

Results of the sensory evaluation of samples of KZ (Table 7) on day 1 showed that there is significant different $(P<0.05)$ on the taste of each sample ranked by the sensory panelists because calculated values (T. cal) are greater that the tabulated values (T. tab). ${ }^{29,30}$

The summary of sensory analysis (Table 8) showed that the calculated value is 18.21 , and is greater that the tabulated value (4.03); therefore, there is significant different $(P<0.05) .{ }^{29,30}$ Results in
Table 9 indicated that Kunu zaki (KZ) preserved with ginger extract concentrate (GEC) samples 222 (KZ preserved with 15\% GEC), 232 (KZ preserved with $20 \%$ GEC) and 242 (KZ preserved with $25 \%$ GEC) are significantly having better taste than samples 200 (KZ preserved with $0 \%$ GEC), 201 (KZ preserved with 5\% GEC) and 212 (KZ preserved with $10 \% \mathrm{GEC}$ ) probably due to the concentrations of GEC added into the $\mathrm{KZ}$ and storage condition $\left(4-5^{\circ} \mathrm{C}\right)$ the $\mathrm{KZ}$ was stored at for 2 days and immediately after production $(P<0.05) .^{29,30}$

\begin{tabular}{llllll} 
Table I O Results of sensory evaluation (ANOVA) conducted for day 3 \\
\hline Sources of variation & Df & Ss & Ms & F. cal & F. tab \\
\hline Samples & 5 & 6.43 & 1.29 & 4.96 & 4.03 \\
Judges & 9 & 2.36 & 0.26 & & \\
Error & 45 & 34.68 & 0.77 & & \\
Total & 59 & & & & \\
\hline
\end{tabular}

The summary of sensory analysis (Table 10) showed that the calculated value is 4.96 is greater that the tabulated value (4.03) therefore, there is significant different $(P<0.05) .29,30$

Results presented in Table 11 indicated that there is significant different $(P<0.05)$ on the taste of all the samples of $\mathrm{KZ}$ ranked by the sensory panelists on day 3 because the tabulated value (1.18) is greater that all the calculated values (T. cal). ${ }^{29,30}$

Table I I Summary of ranked results of sensory evaluation conducted for day 3

\begin{tabular}{llll}
\hline Samples & T. cal & T. tab & Remark \\
\hline $200-222$ & 1.00 & 1.18 & SD \\
$200-201$ & 0.78 & 1.18 & SD \\
$212-232$ & 0.51 & 1.18 & SD \\
$232-200$ & -0.42 & 1.18 & SD \\
$222-200$ & 1.00 & 1.18 & SD \\
$242-232$ & 0.13 & 1.18 & SD \\
\hline
\end{tabular}

\section{Discussion}

Sensory evaluation results imply that MKZ organoleptic qualities including aroma, colour, taste (mouth feel) and overall acceptability remain accepted by the sensory panelist for $72 \mathrm{hrs}$ especially by the samples of MKZ that have $15 \%, 20 \%$ and $25 \%$ Ginger concentrations in them; while the sample with $0 \%$ (control), $5 \%$ and $10 \%$ samples were less accepted by sensory judges in terms of all the attributes listed $(P<0.05)$.

Also, this study submits that the use of inverted sugar syrup, a honey-like sugar product, in sweetening the MKZ can serve as a means of making available simple sugars including Fructose and Glucose in free form for consumers; the glycemic index of Fructose is 19 compared to that of Glucose which is $100 .{ }^{14}$ Inverted sugar syrup contains high amounts of Fructose; and several studies have shown that the anti-diabetic and hypoglacaemic effect of honey resulted from the Fructose component; owing to the fact that Fructose increase the uptake of hepatic Glucose as well as storage and synthesis of glycogen. ${ }^{14,39,40-42}$ It has been recently reported that Fructose has the ability to lower the blood Glucose in animals' models of diabetes; and the mechanisms involved in this process include prolongation of gastric emptying time and reduced rate of intestinal absorption, stimulation of glucokinase in the hypatocytes which plays an 
important role in the uptake and storage of Glucose as glycogen by the liver under the adipose tissues of the body. ${ }^{14}$

Although, there are some studies that reported contrary opinions regarding the use of honey in the control and management of diabetes mellitus diseases, other several research findings favourably discuss and opined that honey with high amounts of Fructose can be used to manage and control Type 2 diabetes. Hence, the need for larger sample sized; multi-centre clinical controlled studies so that better and reliable conclusion can be drawn. ${ }^{14}$ In essence, the use of inverted sugar syrup to improve the taste of MKZ in this study can conveniently suggest that this developed $\mathrm{MKZ}$ can be consumed in moderation by an individual suffering Type 2 diabetes because the major component of this processed sugar product is Fructose.

Based on the results in this study, the $\mathrm{pH}$ values of samples of Millet-based Kunu Zaki (MKZ) were stable for 2 days, but dropped in day 3 due to the breakdown of complex sugars in the $\mathrm{KZ}$ by the action of micro-organisms and enzymes' activities leading to the increase in the acid level of MKZ samples within $72 \mathrm{hrs}$ of MKZ production. And the results of sensory evaluation revealed that ginger extract concentrate (GEC) added into the processed Kunu zaki (KZ) enhanced the shelf-life of samples 222 (KZ preserved with $15 \%$ GEC), 232 (KZ preserved with 20\% GEC) and 242 (KZ preserved with $25 \%$ GEC) for $48-72 \mathrm{hr}$. This is because these samples $(222,232$ and 242$)$ of $\mathrm{KZ}$ were preferred $(P<0.05)$ by the sensory judges during day 1 and day 2 , respectively.

\section{Conclusion}

In conclusion, the $\mathrm{pH}$ of $\mathrm{MKZ}$ can be controlled for 2 to 3 days by the addition of $15 \%, 20 \%$ and $25 \%$ of GSC, respectively and subsequent storing at $4-5^{\circ} \mathrm{C}(P<0.05)$. This study indicates that this process could serve as the standard operating procedure (SOP) for the commercial production of MKZ for a willing entrepreneur.

\section{Acknowledgments}

None.

\section{Conflicts of interest}

Author declares that there is none of the conflicts.

\section{References}

1. Maji AA, James O, Chigozie OE. Effect of Chemical Treatment and Pasteurization on the Shelf life of Kunun zaki (Sorghum and Maize Gruel). European Journal of Food Research and Review. 2011;1(2):61-70.

2. Olufunke AP, Oluremi KO. Assessment of Nutritional and Sensory Quality of Kunun Zaki: A Home-made Traditional Nigerian Beverage. Journal of Nutrition and Food Science. 2015;5(3):1-3.

3. Adebayor YB, Mark FD, Oluchi AU. Pastuerisation and Chemical Preservative Effects on the Physico-chemical, Sensory Properties and Microbial Qualities of Kunun-Zaki. International Scholars Journals. 2016;2(4):117-123.

4. Mohammed SF, Balen DMA. A Review on the Safety and Quality Associated with Traditional Beverages. Annals. Food Science and Technology. 2016;17(1):203-210.

5. Anyanwu KB, Nsofor LM. Effect of Heat Processing on Refrigerated Shelf life of Concentrated Kunu-zaki Beverage. Journal of Food Science and Technology. 1992;29(1):40-41.
6. Ijeh II, Omodamiro OD, Nwanna IJ. Antimicrobial Effect of Aqueous and Ethanolic Fractions of Two Cereals. Journal of Biotechnology. 2005;4:953-956.

7. Efiuvwevwere BJO, Akoma O. The Microbiology of Kunun-Zaki: A Cereal Beverage from Northern Nigeria During the Fermentation (Production) Process: World Journal of Microbiology and Biotechnology. 1995;11(5):491-493.

8. Nkama I, Agarry OO, Akoma O. Sensory and Nutritional Quality Characteristics of Powdered 'Kunun-zaki': A Nigerian Fermented Cereal Beverage. African Journal of Food Scienc. 2010;4(6):464-370.

9. Awogbenga MD, Ahmadu M, Ozigis AA. The Glycemic Effect of Kunu-zaki on Blood Glucose in non-diabetic Subjects. Proceedings of the 23rd NIFST Annual Conference and General Meeting held in Abuja between 25th to 27th October. 1999; p. 217-218.

10. Adeyemi T, Umar S. Effect of Method of Manufacturing on Quality Characteristics of Kunu-Zaki: a Millet Based Beverage. Nigerian Food Journal. 2004;12:34-40.

11. Solange AKA, Georgette K, Gilbert F, et al. Review on African Traditional Beverages. American Journal of Research Communication. 2014;2(5):03-153.

12. Steinkraus KH. Lactic Acid Fermentation in the Production of Food from Vegetable, Cereal and Legumes. Antonie. Van leeuwentwek. 1983;49(3):337-348.

13. Ayo JA, Okaka JC. Interaction effect of Cadaba Farinose and Crude Extract and $\mathrm{pH}$ levels on Some Physiochemical Properties of Kunuzaki. Proceedings of NIFST Annual General Meeting held in Abeokuta between 23rd-26th November. 1998. p. 31-33.

14. Bobis O, Dezmirean DS, Moise AR. Honey and Diabetes: The Importance of Natural Simple Sugars in diet for Preventing and Treating Different Types of Diabetes. Hindawi Oxidative Medicine and Cellular Longevit. 2018;10:1-12.

15. Oguntoyinbo FO, Tourloumousis P, Gasson MJ, et al. Analysis of Bacterial Communities of Traditional fermented West African Cereal foods Using Culture Independent Methods. International Journal of Food Microbiology. 2011;145(1):205-210.

16. Fapohunda SO, Adewale A. Microbial Load and Keeping Quality of Kunu under Various Preservative Regimes. Journal of Nutrition and Food Sciences. 2012;2(141):1-4.

17. Adegoke GO, Odeyemi AO, Hussien O, et al. Control of Ochratoxin A (OTA) in Kunuzaki (a Non-alcoholic Beverage) using Daniellin ${ }^{\mathrm{TM}}$ (Short Communication). African Journal of Agriculture. 2007;2(4):200-202.

18. Roberts D Hobb's. Food Poisoning and Food Hygiene. 7th ed. In: Mclaunchlin J, Little C editors. UK: Edward Arnold Ltd; 2007. p. 7-13.

19. Lither D, Larsson A, Dave G. Environmental and Health Hazards Ranking and Assessment of Plastic Polymers Based on Chemical Composition. Journal of Science of the Total Environment. 2011;409(18):3309-3324.

20. Osuntogun B, Aboaba OO. Microbiological and Physico-chemical Evaluation of Some Non-alcoholic Beverages. Nutrition Journal of Pakistan. 2004;3(3):188-192.

21. Creppy EE. Update of survey, regulation and toxic effects of mycotoxins in Europe. Toxic Let. 2002;127(1-3):19-28.

22. Douglas LP, Carlos EA, Sonia EGP, et al. Microbial Toxins in Foods, Algal, Fungal and Bacterial. In: William H, Carl KW, editors. Food Toxicology. UK: CRC Press. 2001. 222 p.

23. Adegoke GO, Letuma M. Strategies for the Prevention and Reduction of Mycotoxins in Developing Countries. In: Makun HA, editor. 
Mycotoxins and Food Safety in Developing Countries. Croacia: InTech; 2013.

24. Federal Institute of Industrial Research, Oshodi. Production of Soft Drinks from Nigeria Ginger. Technical Information Bulletin for Industries. 1998;4-6:1-4.

25. Federal Institute of Industrial Research, Oshodi (n.d.): Brochure, FIIRO, Federal Ministry of Science and Technology. 1998. 6 p.

26. Less R, Jackson EB. Development of Ginger Extract Concentrate. Leonard Hills; 1989. p. 21-37.

27. Irvine FR. West Africa Crops. London: Oxford University Press; 1995. p. $40-42$.

28. Muhammad SF. Production of Sugar Syrup. A Practical Guide for Beverage (Soft drinks) prepared for Centre for Research and Entrepreneurship Development (CRED), Federal Polytechnic KauraNamoda. 2012. p. 29-30.

29. Ihekoronye AI, Ngoddy PO. Integrated Food Science and Technology. London: Macmillan Publishing Ltd; 1985. p. 306-307.

30. Lawless HT, Heymann H. Sensory Evaluation of Food: Principles and Practices. 2nd ed. New York: Springer Science; 2010. p. 303-320.

31. Iwe MO. Handbook of Sensory Methods and Analysis. Nigeria: Rojoint Communication Services Ltd; 2002. p. 71-78.

32. Iwe MO. Current Trends in Sensory Evaluation of Foods. 1st ed. Enugu, Nigeria. Rojoint Communication Services Ltd; 2007. p. 136-139.

33. William M. The Importance of Food $\mathrm{pH}$ in Commercial Canning Operations. 1992.

34. Obulunde FO, Ogunkoya MO, Oni VA. Mineral Composition, Shelf Life and Sensory Attributes of Fortified Kunuzaki Beverage. Acta Sci Pol Technol Aliment. 2006;5(1):155-162.

35. Agarry OO, Nkama I, Akoma O. Production of Kunun-zaki (A Fermented Cereal Beverage) Using Starter Culture. International Research Journal of Microbiology. 2010;1(2):18-25.
36. Edward KC, Ohaegbu CG. The Effect of Ginger and Garlic on the Microbial Load and Shelf Life of Kunun-Zaki. Journal of Applied Pharmaceutical science. 2012;2(5):150-153.

37. Nwachukwu E, Achi OK, Ijeoma IO. Lactic Acid Bacteria in Fermentation of Cereals for the Production of Indigenous Nigerian Foods. African Journal of Food Science and Technology. 2010;1(2):021-026.

38. Innocent OO, Mariam YO, Blessed K, et al. Microbial Evaluation and Proximate Composition of Kunu zaki, an Indigenous Fermented Food Drink Consumed Predominantly in Northern Nigeria. Internet Journal of Food Safety. 2011;13:93-97.

39. Kardrivelu A, Gurtu S. Potential Benefits of Honey in Type 2 Diabetes Mellitus: A Review. International Journal of Collaborative Research and Internal Medicine and Public Health. 2013;5(4):199-216.

40. Erejuwa OO, Nwobodo NN, Akpan JL, et al. Nigerian Honey Amileorates Hyperglycemia and Dyslipidemia in Alloxan-induced Diabetes Rats. Nutrients. 2016;8(3):95.

41. Enginyurt O, Cakir L, Karatas A, et al. The Role of Pure Honey in the Treatment of Diabetes Mellitus. Biomedical Research. 2017;28(7):3305-3312.

42. Romero-Ortiz AA, Martinez-Carrillo BE, Rillo AG, et al. Honey and Type 2 Diabetes Mellitus: Reconstruction of Problematic Field Using the Lekatosian Method. Journal of Pharmacy and Biomedical Sciences. 2017;12(6):1-14.

43. Dean RB, Dixon WJ. Simplified Statistics for Small Numbers of Observations. Analytical Chemistry. 1951;23(4):636-638.

44. Smith JS. Evaluation of Analytical Data. In: Nielsen SZ editor. Introduction to the Chemical Analysis of Foods. India: CBS Publishers \& Distributors; 2002. $51 \mathrm{p}$. 